\title{
A Program of Art Education Exploring Life Issues —By Two Nudity Artworks
}

\author{
Yu-Ching Hsieh \\ National Chin-Yi University of Technology, Taichung, Taiwan
}

\begin{abstract}
The purpose of this essay is to design an art education program based on post-modernist concepts to lead students to contemplate the meaning of life and build their insight about visual imagery of artworks, by looking at two nudity artworks—Edward Munch’s “Puberty” and Frida Kahlo’s “The Broken Column”. The program will look at metaphors and the significance of life in these two artworks. Over and above exploring relative philosophical, aesthetic, historical, hermeneutic, and semiotic domains, the program will be designed in such a way that the intrinsic quality of art will be emphasized. The research method is a visual narrative approach, including image interpretation. Its purpose is to encourage students to consider how they experience life, the emotional elements of life, as well as the spiritual progression, physiological development, anxiety and suffering of life, etc.. The program will also provide students with diverse information and potential ways of thinking about and discussing the issues of life and art by using questions in a learning list. This program will be employed and executed over two hours of class time. It could become the general education teaching material or art curriculum.
\end{abstract}

Keywords: interpretation, art curriculum, life issue, metaphor, narrative

\section{Introduction}

In this essay, two nudity artworks, Edward Munch’s (1863-1944) “Puberty” and Frida Kahlo’s (1907-1954) "The Broken Column" are chosen for study in an art program to emphasize the significance about life. The purpose of this art program is to build the students' insight about visual imagery of artworks, and influence individual students to rearrange his or her attitude to be more contemplative, perceptive and healthy.

This program will be employed and executed over two hours of class time. It could become the teaching material for the general education curriculum in the university. The basic epistemology integrates the theory of some post-modernist concepts, Gadamer’s (Hans-Georg Gadamer, 1900-2002) hermeneutics theory, and is inspired by other relative theories to contribute to the design of the art curriculum program.

There are two questions that must be settled in this essay. The first is, what kind of content should be considered and included when teachers teach these artworks? The second is, what method of interpretation will be used to lead students to think about these two artworks?

For the first question, this essay will probe into what the vital life issues in art are. What could the contents of the art program focus on? It will look at the inspiration of artistic feeling and critical thought about life, metaphors of life and our critical attitude about images. The program will contain the details of these two artists' life experience, to show how artists connect their experiences with images in their art, and also contain multiple 
messages and diverse questions, which could lead students to contemplate life issues philosophically.

For the second question, the essay will probe how these approaches could lead students to philosophically examine life issues in artworks. On the one hand, the author will give some framework to help students to seek the multiple meanings within artworks; on the other hand, the author believes students' free self-interpretation is also important, and this method of personal interpretation can grow students' ability to feel, and think creatively.

The following part of this essay will start to explore the relative theory more deeply for the above two questions. And it will offer some principles for designing art curriculum to develop a practical art program. The purpose is to help students build a powerful sense, a positive attitude towards life, and image insight about art through their appreciation of these two works.

\section{The Background Theory}

\section{Contents-Life Issue in the Artworks}

The significance of life issue. German hermeneutics philosopher Gadamer reminds us to think about the inspiring ideas of life in works of art. He claims that experiencing art could stimulate our soul to think about our life. Works of art are not just formed with aesthetic quality. Art has meaning and content, and it can’t be isolated from its real-life inspiration (Gadamer, 1989). Roberts (2005), says "the history of art was replete with individuals, like myself, who experienced their lives intensely, thought deeply about all manner of things” (p. 2).

What might be the appropriate approach of an art program for inspiring our life value and attitude? Gadamer believes that if art had no social significance, religions meanings, moral implication, or any humanities purpose, it would become something that has no meaning, and something that cannot be understood (Chan, 2011). He indicated further that "art as a religion of culture" or "art as a provocation" has its background in Western history. In the 19th century, great artists proclaimed that they were only artists for the sake of art, and trying to solve the problems they experienced and observed (Gadamer, 1986, pp. 7-10). As for Michel Foucault (1926-1984), he also commented that a real artist would fight with the represented system that was already established within a society. Also, artists will not just follow and copy the rule of image, but include social symbols in their artwork (Chalumeau, 1996). Maurice Merleau-Ponty's (1908-1961) philosophy has similar comments about art as well. Merleau-Ponty recognized the connection between artists and their work. He believes that the life of an artist "follows" the life of his art. He noted that modern arts in painting does not invalidate the old, but challenges the past and the tradition (Adam, 1996, pp. 141-142).

Consequently, all of these perspectives conclude that features of worthy art can evoke philosophical thinking about life. Even in Barthes' (Roland Barthes, 1915-1980) Post-Structuralism, his thinking is different from his opinion in earlier structualism. His values become more directed towards caring about human life when talking about art (Adam, 1996, pp. 157-160).

People do not necessarily just adore the great artists and their work. In fact, many great creative achievements of art really affect our thoughts and life. Gadamer (1986) suggested us to see art with the concept that "the arts of language may well play a special part in solving the problems that we have set ourselves” (p. 17). Although every individual has his or her own problems in their lives, they could search for some potential inspiration in the infinite possibility of artistic imagery by the life issue of artists to think about their lives more profoundly.

Thus, three dimensions should be considered for the contents of an art program: (1) It should examine artists' life experience, that has influenced artists' imagery of pleasure, anger, lament, sublime, splendor, love, 
sympathy, beauty, suffering, fear, etc.; (2) It should examine artists' critical view against traditional image or thought; and (3) From the opposite aspect of spectator, it should leads participants to examine the ideology, which may exist within the artwork itself. Under the considerations the author mentioned above, the chosen images must have some moving inspiration, which can contribute to students' thought, insight, and ability of visual interpretation of art.

Metaphor of life. How artists use their images to express meaning in life is another vital content of an art course. The communicative model of image metaphors possesses incalculable power that is different from language.

Adams (2006) illustrates that "most attempts to define the origins of art emphasize visual metaphor as a significant source of creative thinking” (p. 20). To Sullivan, Macleod and Holdridge, "artists are theorists; they question, observe, analyze, synthesize, and hypothesize as scientists do and shape thought into conceptual images, which are often metaphorical” (Marshall, 2007, p. 32).

Stewart and Walker suggest that art curricula must foster students' ability of "metaphorical understanding" and "link academic subject matter with life-focused issues" (Stewart \& Walker, 2005, pp. 25, 111).

Adams (2006) demonstrates that "In visual metaphor, form rather than words inspire imagery and associations are made between one image and another” (p. 20). Consequently, an art program's curriculum must lead students to seek how artists create association or similarity between image and their intended message to imply meanings. Thus, learning how to catch intended messages and metaphors about life is vital content in the art program as well.

When the art program focuses on the inspiration of artistic feeling and critical view about life, metaphors of life and our critical attitude about images, the author believes it will contribute to students' insight about life.

\section{Interpretation}

Barrett (2000) points out that "works of art present us with views of the world and experience that can provide us with insights, information, and knowledge, but we can only access these through interpretation” (p. 7). And interpretation can come from many approaches or activities for understanding the artworks.

In this essay, the art program will interpret two artworks by a visual narrative approach, using a group of ways to help students to consider the life issues in artworks. These methods include images descriptions, story narratives, exploration of metaphors, direct questions, discussing, writing activities, art creation, and researching information, which could lead students to think about the topic. Below are basic descriptions of the approaches suggested and theories used.

Using questions. Gadamer suggested that using questions can deepen our experience of artworks and he called the process of experiencing art "fusion of horizons" (Chan, 2011, p. 219). When people experience art, they should try their best to use the cognitive thought, plunge their sensation, and open their minds to catch the true meaning in art itself for procuring inspiration. However, people are still affected by their "prejudices" and can only achieve the limited realization, and when people change their perception, their understanding will change again. This idea denotes that there is no standard experience from art. Thus, "fusion of horizon" is a mental act of exploring meaning in an artwork. Gadamer suggested that in the process of experiencing art is asking questions about the art and we answering them by ourselves through art itself (Chan, 2011; Gadamer, 1989).

By this way, the approach of using question to interpret the artwork will make art program be more 
effective by giving students cues for imaginative thinking, feeling, and creative interpretation using their personal perceptions.

Seeking the meaning in artworks and respect the experience of audiences (students). Barthes (1981) conceived the notion of "stadium" and "punctum" in his book Camera Lucida: Reflections on Photography (Lin, 2006, p. 4). It could be used to explain the process of experiencing art and culture activity. Barthes claimed that although "stadium" encompasses our knowledge and nature which causes our interest in art creation, it is not the pivotal factor that evokes love of artwork. When we are touched by an artwork, "Punctum" is the real reason that causes us to be emotionally moved by that art. "Punctum" is built by different viewer's basic life experience. This opinion reflects Barthes' concept of "death of the Author” (Lin, 2006, pp. 4-5).

"Death of the author" means individuals will have various reactions when they face an artwork, because of their different life backgrounds. Also, "punctum” corresponds to Gadamer's point about "fusion of horizons", that viewers have inherent "prejudices". They both claim that the audiences' background life experience is the crucial factor when experience art. Although Barthes and Gadamer give dissimilar theories of the progress of viewing art, they still propose the same ultimate goal behind seeing art, i.e., to search for an inspirational meaning in artwork.

According to above opinions, this is the direction for interpretation. On the one hand, art interpretation must include revealing how to discover the marvel and fascinating side in art, to lead students to catch the sense and perspective in art with enthusiasm. On the other hand, art interpretation should consider students' self-identifying as well.

Terry Barrett (2000) suggests that "We can think of acts of interpreting as having two poles, one personal and individual, and the other communal and shared” (p. 8). Communal interpretation could guide students to seek the historical past and meaning of artwork itself. Individual interpretation could help students to identify themselves. So the principle of interpretation is "seeking balance between the personal and communal" (Barrett, 2000, p. 11). In other words, interpretation should be seeking the meaning of artworks together and respecting the experience of individual students.

Story narrative. Using story narrative is another important concept for designing art curricula. Post-modernist remind us to concern individual phenomena instead of seeing things with grand principle. Pearse (1997) recommend us to look at the features that belong to every single thing and individual, which cannot be simplified by the formula of "one-size-fits-all”. Under this idea, two notions are created: (1) Every matter, and everyone has its story that cannot be fully analyzed by broad categories. Relating to art and artist, the art curricula should be designed on a specific issue, and discussed deeply; and (2) When art curricula leads students to seek the sense in artworks, keep in mind that helping students to raise awareness is the goal, so every single student's self-experience must be considered.

Many educative scholars regard narrative as a valuable way for "helping students understand different perspectives and complexities involved in problem-solving and social relationships” (Zander, 2007, p. 192). According to Zander (2007), narrative could include students' own art, teachers' experiences with art, the stories of artists, and interpretations of art works. Through storytelling, narratives could lead students to consider meanings, messages, and various values about life. Narrative also can help students to identify themselves. So, this is why this art curriculum has just chosen two pictures and focuses on the topic of life 
issues. And this is one of the approaches to use stories narrative to provide students some basic messages about artists and the artworks.

Therefore, the approach of interpretation should include historical information, stories, student narrative about artworks and artists, giving questions, and supplying direction to encourage students to think, discuss, write, or paint encouraging students to think about themselves.

\section{The Art Program Exploring Life Issues-By Two Nudity Artworks}

To sum up the idea we discuss above, this art program here will give image description, communal stories, discussing questions and exploring metaphors of life about these two artworks first. Then synthesize these to go to the developing potential instruction and activities. It will include sense of significance about life, critical thinking about naked figure image, and self-identifying by activities.

\section{Edward Munch's “Puberty”}

Original interpretation-Image description with no judgment. A naked, long hair, young girl seated on the edge of a bed. Her body doesn't relax. With eyes opening wide, seeing the spectator outside the artwork directly, but her eyesight doesn't focus on us, and her two arms cross before her body and firmly fastened legs seem longer than normal. There's a strange shadow like another giant girl's long hair on the back. The shadow and the body seem connected tight. The colors of sheet and pillow are white, and others places are all bleak and dark. The texture and lines are dynamic (see Figure 1).

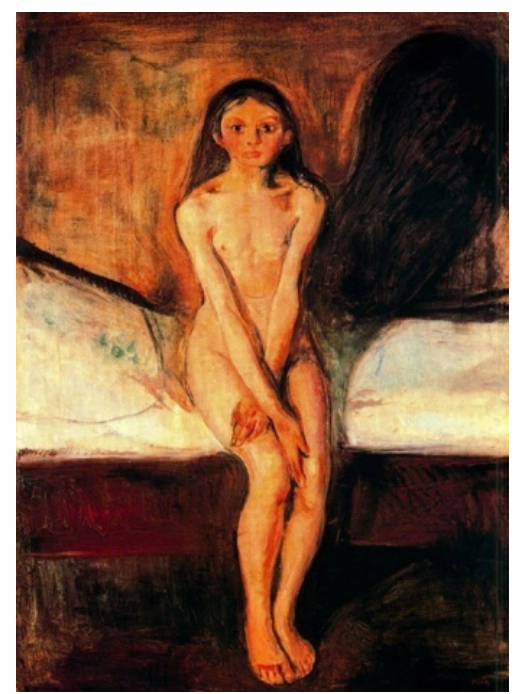

Figure 1. "Puberty” (Munch, 1895), oil on canvas, $150 \times 110$ cm, Nasjonalgalleriet (National Gallery), Oslo.

\section{Communal story about artwork}

(1) Munch's story.

"Any biographical account of Munch cannot fail to mention the incidences of illness and death in his immediate family” (Cordulack, 2002, p. 23).

Munch’s (Edward Munch, 1863-1944) Families' sickness and death affect him deeply. Munch was born in Norway. His father was a doctor, but his family was poor, because his father worked for poor people, and usually worked with no payment. More than that, when Munch was five years old, his mother died due to transmission of a patient's pulmonary tuberculosis. Nine years later, his sister died from the same illness. And 
his father was so sad and became violent. These factors in his life brought him a lot of suffering experiences (Ho, 1996; Hu, 2005).

Munch said:

My whole life has been spent walking by the side of a bottomless chasm, jumping from stone to stone. Sometimes I try to leave my narrow path and join the swirling mainstream of life, but I always find myself drawn inexorably back towards the chasm's edge, and there I shall walk until the day I finally fall into the abyss. (Edvard Munch Art Quotes, 2013)

\section{(2) Story of Munch's art.}

Munch's artworks reflect the anxiety and emotion inside his heart. He insisted on exploring the suffering in life for the sake of seeking the reason of life existence. His artworks examine the systematic themes about life, such as life, death, love, sex, illness, pain, suffering, isolation, and finally expiation (Gariff, Denker, \& Weller, 2009).

Munch talk about his art by himself:

In my art I have tried to explain to myself life and its meaning. I have also tried to help others to clarify their lives. Just as Leonardo da Vinci studied human anatomy and dissected corpses, so I try to dissect souls. The way one sees is also dependent upon one's emotional state of mind. This is why a motif can be looked at in so many ways, and this is what makes art so interesting. (Edvard Munch Art Quotes, 2013)

Munch's exuberant brushstrokes and his interest in conveying mood were inspired the Expressionists. From the effects of industry, which led to a new urban iconography, Munch like many other early-twentieth-century artists would find a new way to subvert the classical tradition. His dynamic lines and colors express “a new depth in conveying states of mind. Affected by a series of personal tragedies, Munch's art has an overtly autobiographical flavor” (Adams, 2006, p. 507).

Furthermore, Munch gave a lot attention to the subject of physiology. He developed an awareness of physiology in his artworks. Physiology is the branch of biology that deals with the function of the vital processes of living, including reproduction, growth, circulation, respiration, and metabolism (Cordulack, 2002, p. 97). For Munch, he wanted to recognize the real significance of life through physiology in his art. For example, "Puberty" is such a theme to concern humans' process of life.

Discussing questions. (1) What imagery does Munch express in the work? Is there any metaphor or symbol about life? Please describe in detail; (2) What kind of feeling or reason may have lead Munch to draw this image? What could be the relevant story? (3) How is the use of nudity related to life? (4) How does Munch use expressionism? Could this art work express the agonizing feeling of life? How are the functions of texture, colors, and lines used in this case? and (5) Do you have any agonizing experiences? Imagine a situation and describe how you faced it?

Metaphor of life. The goal is to lead students to understand how artists use metaphors to express their abstract feelings about life, encourage students to seek the diverse possibility of metaphors in this artwork by themselves first, and give appropriate help such as following:

(1) The posture of sitting on the edge of bed with naked body: the position of pubescent physical and mental features, the period of development in life; (2) Opening wide eyes, not focusing her eyesight: being perplexed and anxious; (3) Seeing the spectator outside the artwork directly: self-consciousness, feeling of existence; (4) Not relax: the position of anxiety, misgiving; (5) White sheet and pillow, the ambiance of light: pure, innocent, future; (6) Dark backward and the strange showdown: dark side in heart, desire; (7) The shadow and the body seem connected tight: An situation in heart of agonizing between desire and morality. 


\section{Frida Kahlo's “The Broken Column”}

Original interpretation-Image description with no judgement. Kahlo stands before a desolate and cracked plain that is arid and lifeless. Kahol's countenance sees a spectator outside the artwork with no focus. Her body is broken and tied tight with steel strip. An artificial Column made of steel penetrates through her body from her jaw to the waist, and a lot pins are piercing her body (see Figure 2).

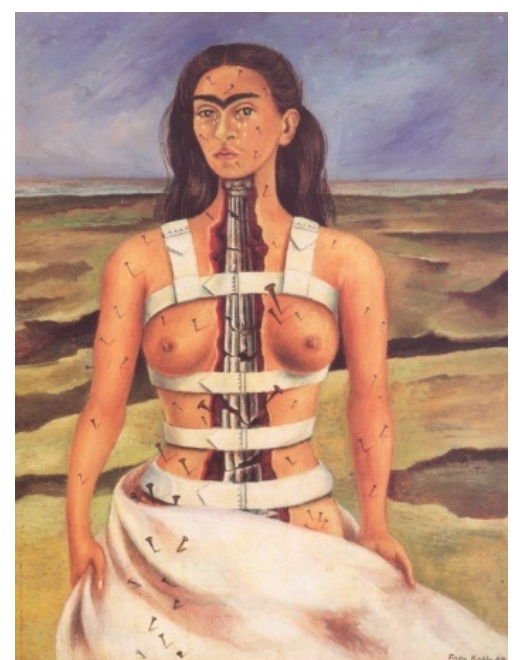

Figure 2. “The Broken Column” (Kahlo, 1944), oil on canvas, $40 \times 30.5 \mathrm{~cm}$, Museo Dolores OlmedoPatiño, Mexico City.

\section{Commual story about artwork.}

(1) Kahlo's story.

Kahlo (Frida Kahlo, 1907-1954) was born in Mexico, her father was a photographer of Hungarian Jewish descent, and her mother was Spanish and Native American. She was bright and well educated. In 1925, due to a bus accident that nearly killed her, Kahlo suffered serious injuries, and was never again free of pain. After that Frida began to take up painting and expressed her suffering that comprised 32 operations in 29 years (Esaak, 2013; Lucie-Smith, 1999). She said, “My painting carries with it the message of pain” (Kahlo Art Quotes, 2013).

The pain in Kahlo's life is not only the results of the injuries but also the experiences between her and her husband Diego Rivera (1886-1957). She adored Rivera, and said, "His capacity for work breaks clocks and calendars” (Kahlo Art Quotes, 2013).

She met Rivera when she was in the Preparatoria (National Preparatory School), the most prestigious educational institution in Mexico, when Rivera had just returned home from France and had been commissioned to paint a mural there. Rivera was a communist militant and his artistic reputation was expanding in the United States in 1930 (Lucie-Smith, 1999).

However Rivera didn't really fulfill his duty as a husband, and Kahlo was hurt and said, "I cannot speak of Diego as my husband because that term, when applied to him, is an absurdity. He never has been, nor will he ever be, anybody's husband” (Kahlo Art Quotes, 2013).

(2) Story of Kahlo's art.

A critic of Kahlo's exhibition wrote: "It is impossible to separate the life and work of this extraordinary person. Her paintings are her biography”. Some critics categorized Kahlo with surrealists, and she was invited to participate in some activities with them, but she said, "They thought I was a Surrealist, but I was not. I never paint dreams or nightmares. I paint my own reality” (Lucie-Smith, 1999). “I paint self-portraits because I am so 
often alone, because I am the person I know best” (Kahlo Art Quotes, 2013). For Kahlo, she painted her life as she saw it, none were surreal (Watt, 2012).

"Kahlo's themes were almost exclusively about women: women's bodies, birth, death and survival". Originally, Kahlo was known as Diego's wife, but now she has her own "iconic status in feminist and Hispanic culture” (Esaak, 2013).

Discussing questions.

(1) What imagery does Khalo express in the work? Is there any metaphor or symbol about life? Please describe in detail.

(2) What kind of feeling or pain may lead Kahlo to draw this image? What is the relevant story?

(3) Why does Kahlo express her using nudity? How is it related to life?

(4) How does Khalo express her own life? Can art express the anguish of life? Describe the functions of texture, colors, and lines in this case.

(5) Do you have any experience of anguish in your life? Imagine a situation and think about how you faced it?

Metaphors of life. Let students seek the diverse possibilities of metaphors of life in this artwork by themselves first, and give appropriate help like: (1) Broken body: broken heart, pain of body, aguish in life; (2) Pierced with pins: tears, pain, and suffering in life; (3) Desolate and cracked plain: alone, bleak feeling; (4) Steel column and strip that ties her body: limitation, being constrained; and (5) Calm countenance: artist's self-consciousness, feeling of existence.

\section{Developing Potential Instruction and Activities \\ Sense of significance of life.}

Existentialist philosopher Heidegger (Martin Heidegger, 1889-1976) reminded us to think about our existence. He tried to find an authentic mode of our being that facilitates the experience of "concern" when we face some difficulty and pain in life. In other words, the consciousness of life existence comes from our reflection. And concern comes from some kind of difficult experience (Magee, 1998).These essay's two art examples were both created by artists who had experiences of anguish in their life and both wanted to express their life and make meanings about life by their art. This fact supports the theory of Heidegger.

Munch's art "Puberty", though inspired by physiology, is not about science of biology, it's about the consciousness of life. "The Broken column” also has the same focus. We can examine the colors, lines, texture, metaphors and symbols etc. and how they are used in these artworks to see how they reflect the theme of life.

\section{Critical thinking about naked figure image.}

Maurice Merleau-Ponty recognized the relationship between our body, perception, and art expression. He theorizes, "The experience of our own body, reveals to us an ambiguous mode of existing". It is "always sexuality and at the same time freedom, rooted in nature at the very moment when it is transformed by cultural influences, never hermetically sealed and never left behind". Our "body is substantial, how is it possible for us to experience in ourselves a pure soul from which to accede to an absolute Spirit?” (Adam, 1996, pp. 141-142).

When leading students to think about the issue of naked images, and its relation with life, there are some questions that could be considered.

Do these two artworks properly use naked figures to express their intended meaning, and do they express some critical provocation in the images? 
How do these two artists express the existence of life by using images of the naked figure? Do they really express a more profound sense about life?

Everybody owns their bodies. Do you recognize the physiological phenomena of your body, accept your body, and have enough confidence to express yourself like a dancer or performance artist?

Is there a difference between expressing yourself confidently and pleasuring others but losing yourself? What is the concept of self-consciousness of existence?

Do these two artworks differ from the sexual images in media? If they are distinguishable, how different are they?

\section{Self-identifying by activities.}

Every student's individual body goes through different physiological phases during various periods of life development. There are some inevitable phenomena, suffering, and emotions that happen to each of us during our lives. Here are two activities for students:

(1) Write a 1,000-words report: please ask a question about this two pictures, and answer it by yourself;

(2) Draw a picture about your painful experience in life, using two metaphors of life at least, and talk about it to share with others.

\section{Conclusions}

The purpose of this art curriculum program is to allow students to consider how these two artworks express experiences and imagery about life, how students could identify themselves by examining these two artworks. It includes some possible approaches to help students think deeply, creatively, and diversely to help each student establish a diverse and profound insight about life issues. According to the post-modernist, people need not only adore the authority of art, but also need some critical views. However, this art program can always lead students to feel, think, and develop the open mind by examining art. The author also says that the powerful magic of art shouldn't be denied, and the life issues embedded in art, these are all important elements to include in approaches to teaching art.

\section{References}

Adams, L. S. (1996). The methodologies of art: An introduction. Boulder, C.O.: Westview Press.

Adams, L. S. (2006). The making and meaning of art. London: Laurence King Publishing Ltd..

Barrett, T. (2000). About art interpretation for art education. Studies in Art Education, 42(1), 5-19.

Barthes, R. (1981). Camera lucida: Reflections on photography. NY: Hill and Wang.

Chalumeau, J. L. (1996). Lectures de L' art (Interpretation of Art). (Y. L. Wang \& H. M. Huang, Trans.). Taipei: Yuan-Liou Publishing Co., Ltd..

Chan, W. W. (2011). Introduction to Gadamer's hermeneutics: “Truth and method”. Taipei: San Min Book Co., Ltd..

Cordulack, S. W. (2002). Edvard Munch and the physiology of symbolism. London: Fairleigh Dickinson University Press.

Edvard Munch Art Quotes. (2013, November 19). The painter's keys. Retrieved from http://quote.robertgenn.com/auth_search.php?authid=415

Esaak, S. (November 19, 2013). Artists in 60 seconds: Frida Kahlo. [About com. art history]. Retrieved from http://arthistory.about.com/cs/nameskk/p/kahlo.htm

Gadamer, H. G. (1986). The relevance of the beautiful and other essays. (N. Walker, Trans.). New York: Cambridge University Press. (Original work published 1977).

Gadamer, H. G. (1989). Truth and method. (J. Weinsheimer \& D. G. Marshall, Trans.). New York: Seabury Press. (Original work published 1960).

Gariff, D., Denker, E., \& Weller, D. P. (2009). The world's most influential painters and the artists they inspired. (L. Q. Jiang \& M. X. Chen, Trans.). Taipei: New generation. 
Ho, C. K. (1996). Munch: The pioneer of scandinavia expressionism. Taipei: Artist.

Hu, Y. F. (Ed.). (2005). The scream of life: Munch. Art Gallery, 47, Taipei: Greenland International Book Co., Ltd..

Kahlo Art Quotes. (November 19, 2013). The painter's keys. Retrieved from http://quote.robertgenn.com/auth_search.php?name=Kahlo

Kahlo, F. (1944). The broken column. Retrieved from: http://www.all-art.org/art_20th_century/kahlo4.html

Lin, P. H. (2006). Foundation of art appreciation ( ): Structuralism, post-structuralism, and deconstructionism. Art Appreciation, 2(11), 22-27.

Lucie-Smith, E. (1999). Lives of the great 20th-century artists. London: Thames and Hudson.

Magee, B. (1998). The story of philosophy. New York: DK Publishing, Inc.

Marshall, J. (2007). Image as insight: Visual image in practice-based research. Studies in Art Education, 49(1), 23-41.

Munch, E. (1895). Puperty. Retrieved from http://www.ibiblio.org/wm/paint/auth/munch/

Pearse, H. (1997). Doing otherwise: Art education praxis in a postpadigmatic world. In J. W. Hutchens, \& M. S. Suggs (Eds.), Art education: content and practice in a postmodern era (pp. 31-39). Reston, VA: The National Art Education Association.

Roberts, T. (2005). Teaching real art making. Art Education, 58(2), 40-46.

Stewar, M., \& Walker, S. (2005). Rethinking curriculum in art. Worcester, MA: Davis Publications.

Watt, G. (2012). Frida Kahlo. [The British Journal of General Practice]. Retrieved from http://www.ncbi.nlm.nih.gov/pmc/articles/PMC1463226/

Zander, M. J. (2007). Tell me a story: The power of narrative in the practice of teaching art. Studies in Art Education, 48(2), 189-203. 